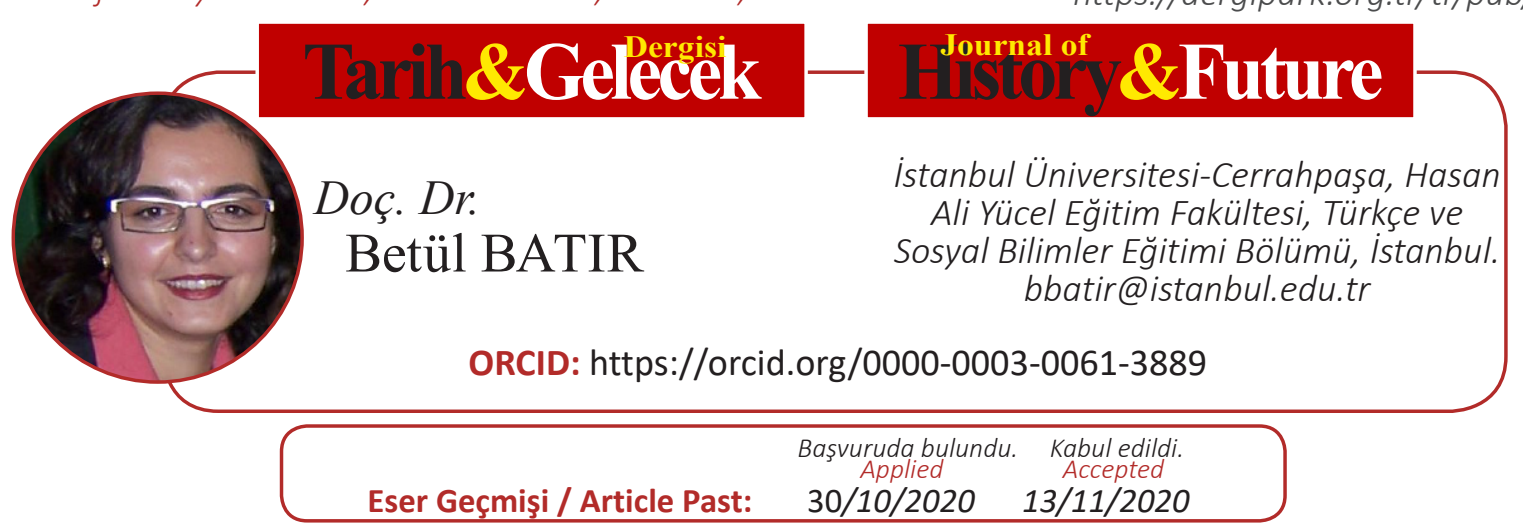

Araştırma Makalesi

DOI: http://dx.doi.org/10.21551/jhf.811850

Research Paper

Orjinal Makale / Orginal Paper

\title{
Sağlıkla Gelen Bir Ziyaret: İsmet Paşa Bursa'da (8 -31 Temmuz 1927)
}

\author{
A Trip for Health Purposes: Ismet Pasa is in Bursa (8 -31 July 1927)
}

$\ddot{O} \mathbf{z}$

Bursa şehri 1927 yılının Temmuz’unda önemli bir konuğunu misafir etmekteydi. Başbakan İsmet Paşa ve ailesi üç hafta Bursa'da Atatürk Köşkü’nde konaklamıştı. Aynı tarihlerde Cumhurbaşkanı Gazi Mustafa Kemal Paşa da İstanbul'da Dolmabahçe Sarayı'nda istirahat etmekteydi. Başbakan İsmet Paşa daha sonra tatilini İstanbul'da sürdürmüştü. İki lider de aslında dinlenmenin ötesinde çalışmalarına devam etmekteydi. Gazi Mustafa Kemal Paşa bu süre zarfında Nutuk isimli eserini kaleme alırken İsmet Paşa da devlet ile ilgili çalışmalarına ara vermemişti. İstanbul'da kaldıkları süre içerisinde birlikte çalışmaya devam etmişlerdi. İsmet Paşa'nın Bursa'da bulunmasının nedeni sadece tatil ve dinlenme değil kendisine rahatsızlık veren sağlık problemiydi. Sağlık turizminde önemli bir yer tutan Bursa kaplıcalarından faydalanmak üzere Başbakan İsmet Paşa üç hafta süreyle Bursa'da kalmıştı. Bursa'da kaldığı süre içerisinde bir taraftan tedavi olan İsmet Paşa diğer taraftan da şehrin ekonomik, sosyal ve kültürel gelişmeleriyle de yakından ilgilenmiş ve yetkilerle görüşüp bilgi toplamıştı. Yakından ilgilendiği ve yerinde tetkik ettiği konulardan birkaçı Bursa'da açılan fabrikalar, tarım sektörü ve hayvancılık gibi konular olmuştu. Çalışmamızda İsmet Paşa'nın Bursa'da geçirmiş olduğu üç haftalık zaman zarfında kendisini karşılayanlar, ziyaret edenler, kendisine bilgi verenler, Paşa’nın ziyaretleri, teftişleri, kutlamalar, Bursa hakkındaki görüşleri, kaplıcalar, dönemin gündemindeki olayları konu yapan basında yer alan haberler 1şığında günlük programı ele alınmıştır. Gazetelere yansıyan haberler sıralanırken Bursa'nın çok yönlü bir şehir olarak sahip olduğu değerlere (ekonomik, kültürel, sosyal, siyasi, sağlık turizmi, spor vb.) İsmet Paşa’nın ziyaret programı çerçevesinde dikkat çekilmiştir.

Anahtar Kelimeler: İsmet Paşa, Bursa, Atatürk Köşkü, Bursa Kaplıcaları, Karacabey Harası.

\section{Abstract}

Bursa province hosted a great visitor in July, 1927. The Prime Minister İsmet Pasha and his family stayed at Atatürk's House in Bursa for three weeks. Meanwhile, The President Gazi Mustafa Kemal Pasha was resting at the Dolmabahçe Palace in Istanbul. The Prime Minister İsmet Pasha later continued his vacation in Istanbul. Both of the leaders were actually carrying on their work rather than resting. While Gazi Mustafa 
Kemal Pasha was writing his work titled Nutuk during this period, İsmet Pasha also never ceased his work on the state affairs. They continued to work together during their stay in Istanbul. The reason why İsmet Pasha was in Bursa was not only vacation and resting, but also a health problem that disturbed him. The Prime Minister İsmet Pasha had stayed in Bursa for three weeks to benefit from Bursa's thermal springs, which have an important place in health tourism. During his stay in Bursa, İsmet Pasha, while being treated, also closely dealt with the economic, social and cultural developments of the city, met with the authorities and gathered information. Some of the subject matters he was closely interested in and examined on site included the factories opened in Bursa, agriculture sector and animal husbandry. In our study, the three-week period İsmet Pasha spent in Bursa was presented focusing on the people who welcomed him, visited him, informed him, Pasha's visits, inspections, celebrations, his views about Bursa, hot springs, his daily program in the light of the news in the press together with the events on the agenda of the period. In the process of listing the news reflected in the newspapers, the values of Bursa as a multifaceted city including economic, cultural, social and political aspects, health tourism, sports, etc. were pointed out within the framework of İsmet Pasha's visit program.

Keywords: İsmet Pasha, Bursa, Atatürk’s Mansion, Bursa Thermal Springs, Karacabey Stud Farm.

\section{Giriş}

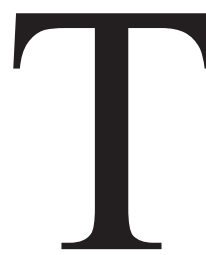

ürkiye Cumhuriyeti Başbakanı İsmet Paşa ayağındaki rahatsızlık nedeniyle ${ }^{1} 8$ 31 Temmuz 1927 tarihleri arasında kaplicalardan faydalanmak üzere Bursa'da bulunmuştu. İsmet Paşa'nın ailesi olarak eşi Mevhibe Hanım, üç yaşındaki oğlu Ömer ve bir yaşındaki oğlu Erdal da beraberindeydi. Bu tarihlerde Nutuk'u yazan Cumhurbaşkanı Gazi Mustafa Kemal Paşa da İstanbul'da Dolmabahçe Sarayı'ndayd $1 .{ }^{2}$ Mustafa Kemal Paşa Nutuk'u yazarken ilgili kişileri Dolmabahçe’ye çağırarak bazı bilgileri teyit etmekteydi. ${ }^{3}$ İsmet Paşa da Dolmabahçe’ye çağrılan kişiler arasındaydı. İsmet Paşa'nın Bursa'da ki istirahatinden sonra dinlenmesine devam ettiği Heybeliada' $\mathrm{da}^{4}$ bulunduğu tarihlerde Nutuk için Mustafa Kemal Paşa ile görüşmeleri olmuştu.

İsmet Paşa'nın ayağındaki rahatsızlık kendisine Bursa'da bulunan şifalı sulardan faydalanmasını gerektirmiş ve burada tedavi maksatı bir aya yakın zaman geçirmişti. Tedavi

1 “Başvekilin Muvasalatı”, İkdam, 2 Ağustos 1927, 1; Sabahattin Özel, Nutuk'a Bir Baklş “Tertip ve Çeviri Hatalart" (İstanbul: Derin Yayınları, 2015), 9.

2 Özel, Nutuk'a Bir Bakış 'Tertip ve Çeviri Hataları, 3 vd; Eminalp Malkoç, Cumhuriyet’ten Büyük Söylev'e Ankara-İstanbul İkilemi (1923-1927) (İstanbul: Derin Yayınlar1, 2014), 176-183.

3 Özel, Nutuk'a Bir Bakış "Tertip ve Çeviri Hataları", 3 vd.

4 İsmet Paşa'nın İstanbul'da Tarabya'ya da misafir edileceği gazetelerde haber edilmişti: "İsmet Paşa Hazretlerinin Bursa'da bir müddet istirahatinden sonra şehrimize gelecekleri malumdur. Haber aldığımıza göre başvekil Paşa hazretleri şehrimizde bulundukları müddet zarfında Tarabya'da ikamet buyuracaklardır”. Bkz."Başvekilimiz İsmet Paşa Hazretleri Bursa'da...”, Cumhuriyet, 10 Temmuz 1927, 1,2. Ancak İsmet Paşa İstanbul'da bulunduğu bu tarihlerde Heybeliada'da kardeşinin yalısında konaklamıştı. 
amaçlı geldiği Bursa kaplıcaları aynı tarihli (1927) Bursa Salnamesi’nde şöyle anlatılmaktaydı:

"Şehrin garbinde ve şehre takriben 2-3 kilometre mesafede kain (Bademlibahçe ve Çekirge) mintıkalarındadır. Her iki mıntıkada bulunan maden sularının terkib-i kimyevileri birbirinden farklı olduğuna nazaran ayrı ayrı mecra ve menbaa maliktirler. Çekirgede bulunan menbaa (çelikli maden suları) zümresinden, Bademlibăgçe mevkiinde bulunanlar da (Kükürtlü maden suları)ndan maduddur. Yalnız (Karamustafa) Kaplıcası bundan hariçtir ve madeniyeti (oligometalik) maden sulart zümresine dahildir", 5

İsmet Paşa Bursa'da kaldığı süre içerisinde Kükürtlü hamamlarını tercih etmişti. Çünkü

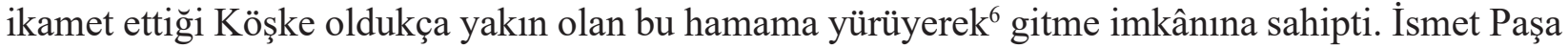
Bursa' da bulunduğu sürece ayağına egzersiz olması için ata binerek şehirde gezintiler de yapmıştı. İsmet Paşa'nın askerde de iyi ata bindiği ve atlara olan ilgisi de ayağının iyileşmesinde takviye edici bir spor mahiyetini görmüştü.

İsmet Paşa ve ailesi Bursa'da Atatürk Köşkü’nde konaklamışlardı. Bugün “Atatürk Evi Müzesi” olarak kullanılan bina ziyaretçilerini ağırlamaktadır. ${ }^{7}$ Başbakan İsmet Paşa'nın Bursa'da kaldığg süre zarfında Köşk, gelen ziyaretçilerle dolmuş taşmıştı. Bu tarihlerde İsmet Paşa'dan başka Köşk'ün bir onur konuğu da Cumhurbaşkanı Gazi Mustafa Kemal Paşa olmuştu. Mustafa Kemal Paşa'nın 15 Temmuz 1927 tarihli ziyaretleri Bursalılar kadar İsmet Paşa’yı da ziyadesiyle onurlandırmıştı.

\section{1. İsmet Paşa'nın Bursa Yolculuğu}

Başbakan İsmet Paşa 7 Temmuz 1927 tarihinde saat on dokuz yirmide özel trenle Karaköy yoluyla Bursa'ya hareket etmiş ve kendisi törenle Ankara Tren Garı'ndan yolcu edilmişti. Trenin hareketine beş dakika kala istasyona gelen İsmet Paşa müfrezeleri teftiş etmiş ve "Merhaba arkadaşlar!" hitabıyla onlara seslenmişti. Törene bütün vekiller, mebuslar, devlet erkânı, kız ve erkek liseleri müdürleri, hukuk mektebi, sefirler ve sair pek çok kişi katılmıştı. İsmet Paşa, hepsinin ayrı ayrı ellerini sıkmış ve Gazi oymağına iltifat etmişti. Kız Lisesi’nin hazırladığı bir buketi kızlardan biri takdim etmiş ve Paşa bu duruma çok memnun olmuştu. Hukuk mektebi öğrencisiyle birlikte resimleri çekilmişti. Tren hareket ederken hazuruna; “- Zahmet ettiniz!” diyerek iltifat etmişti. ${ }^{8}$

Bursa'da Atatürk Köşkü’nde kalacak olan İsmet Paşa’yı Bursa Valisi Fatin (Güvendiren) Bey ${ }^{9}$ Karaköy (Yenişehir)' de karşılamıştı. Bursa' da görkemli bir karşılama töreni hazırlanmıştı.

İsmet Paşa Karaköy-İnegöl yoluyla 8 Temmuz günü saat dokuz otuzda halkın coşkulu

5 “Bursa Kaplicaları", 1927 Bursa Salnamesi (Bursa: Bursa Vilayet Matbaas1,1927), 219- 234.

6 Mesafe yaklaşık 500 m'dir ve yürüyerek yaklaşık 7-8 dakika sürmektedir.

7 Müze Müdürü Sayın Adil Kaya Müze’ye yaptığımız ziyaret sırasında binanın kullanımı ile ilgili bilgiler vermişlerdir. İsmet Paşa'nın konakladığına dair bir malumatları olmadığını ve bu çalışmayı merakla beklediklerini söyleyen Sayın Müdür Adil Kaya Bey’e Müze hakkındaki bilgi ve fotoğraflar için teşekkürü bir borç biliriz. Müzenin diş görünüşü için bkz.Ek.3.

8 “İsmet Paşa'nın Seyahati”, Cumhuriyet, 8 Temmuz 1927, 1.

9 Hüseyin Fatin Güvendiren: D.Lefkoşe-1873, Ö.27.09.1955. Özgeçmişi için bkz. TBMM Albümü (19202010), 1. Cilt, 1920-1950, İkinci Basım (Ankara: Gökçe Matbaası, 2010), 248. 
tezahüratı arasında İnegöl'e varmıştı. İsmet Paşa'yı İnegöl'de karşıllayanlar arasında halktan başka devlet memurları, çeşitli okulların öğretmen ve öğrencileri de bulunmaktaydı. İsmet Paşa hepsine teşekkürlerini sunmuştu. Burada kısa bir süre kaldıktan sonra Bursa'ya hareket etmişlerdi. Şehir baştanbaşa bayraklarla donatılmıştı. Saat on bir otuzda Bursa'ya gelen İsmet Paşa'ya Kız ve Ana mektebi öğrencileri tarafindan birer buket takdim edilmişti. ${ }^{10}$

Bursalılar, İsmet Paşa 'yı büyük coşku ve saygıyla karşılamışlardı. Caddeler geçilmeyecek derecede kalabalıktı. Halkın ve devletin temsilcileri, çeşitli kuruluşların temsilcileri, memurlar İsmet Paşa'yı şehrin girişinde karşılamışlar ve Köşk’te kendilerine arz-1 tazimat (hoş geldiniz) eylemişlerdi. ${ }^{11}$

\section{2. İsmet Paşa Bursa'da}

İsmet Paşa Bursa'ya varışının ertesi günü 9 Temmuz 1927 tarihinde hükümeti, belediyeyi, Cumhuriyet Halk Fırkası (CHF) ile Türk Ocağı'nı ziyaret etmişti. ${ }^{12}$ Bu ziyaretlerden haberdar olan halk İsmet Paşa'yı yol boyunca alkışlarla selamlamışlard. ${ }^{13}$

İsmet Paşa'nın Bursa'da ne kadar kalacağı hakkında basında bir bilgi verilmemişti. Bu konuda gazeteler bir-iki hafta kadar kalacağını öngörmekteydi. ${ }^{14}$ Ancak İsmet Paşa Bursa'da bir aya yakın kalmıştı.

İsmet Paşa 10 Temmuz günü banyolara kadar bir yürüyüş yapmış ve halk kendisine fener alayı düzenlemişti. ${ }^{15}$

İsmet Paşa'nın Bursa'da bulunduğu günlerin başlangıcında Bursa'nın civarından ziyaret için heyetler gelmişti. ${ }^{16} 12$ Temmuz'da Yenişehir'den, 14 Temmuz'da ise Gemlik'ten Paşa'ya hoş geldiniz ziyaretleri olmuş ve Paşa da kendilerini Köşk'te kabul etmişti. Gemlik'ten gelen heyetten başka İsmet Paşa'yı Gemlik'e davet etmek üzere yedi hanımdan oluşan bir hanım heyeti de Paşa'nın hanımı Mevhibe Hanım'la görüşerek kendilerini Gemlik'e davet etmişlerdi. ${ }^{17}$

İsmet Paşa 12 Temmuz günü sabah sekizde İkinci Kolordu Kumandanı Ali Hikmet Paşa'yı kabul etmişti. Sonrasında İsmet Paşa Kükürtlü banyosuna kadar gitmiş ve on ikide Köşke geri dönmüştü. Saat on beşte Mustafakemalpaşa kazasından gelen kaymakam Recep Ragıp, Halk Fırkası mutemedi Vahid, Belediye Reisi Hasan, Türk Ocağı Reisi Doktor Muhlis, Tayyare Cemiyeti muhasibi Ahmet Cevdet beyler ile Karacabey'den kaymakam Ahmet Kemal, Firka mutemedi Nuri, Belediye Reisi Ahmet Muhtar, Tayyare Cemiyeti Reisi ve Firka azasından Mehmet Hulusi ve Orhangazi'den Kaymakam Şaban, eşraftan Refik, Eczacı Reşit beylerle, Orhangazi müdde-i

10 Ahmet Nuri, “İsmet Paşa Hazretleri”, Cumhuriyet, 9 Temmuz 1927, 1.

11 Fotoğraf için bkz.Ek.1. "Başvekilimiz İsmet Paşa Hazretleri Bursa'da...”, Cumhuriyet, 10 Temmuz 1927, 1,2 .

12 İsmet Paşa ile CHF mensubuna ait grup fotoğrafı için bkz. Ek.2.

13 “Başvekilimiz İsmet Paşa Hazretleri Bursa'da...", Cumhuriyet, 10 Temmuz 1927, 1,2.

14 “Başvekilimiz İsmet Paşa Hazretleri Bursa'da...", Cumhuriyet, 10 Temmuz 1927, 1,2.

15 "İsmet Paşa", Cumhuriyet, 11 Temmuz 1927, 2.

16 "Başvekilimize Tazimat”, Hâkimiyet-i Milliye, 14 Temmuz 1927, 1.

17 “İsmet Paşa”, Cumhuriyet, 13 Temmuz 1927, 2; “İsmet Paşa Gemlik’e gidiyor.”, Cumhuriyet, 15 Temmuz $1927,2$. 
idare mümessillerinden gelenleri kabul etmişti. Bundan başka İsmet Paşa Balıkesir, Yenişehir, Orhaneli ve İnegöl'den gelenleri de kabul etmişti. Gelenlerden kasabaları ve kazaları hakkında bilgiler almıştı. ${ }^{18}$

Bursa halkı için 15 Temmuz Cuma günü büyük bir heyecan vardı. Ani gelen bir haberle şehirlerine Cumhurbaşkanı Gazi Mustafa Kemal Paşa'nın teşrif edeceklerini öğrenmişlerdi. Bu ani seyahatin kararını Mustafa Kemal Paşa 15 Temmuz sabahı vermişti. ${ }^{19}$ Gazi'nin Bursa'yı ziyaretinin altıncıs ${ }^{20}$ gerçekleşecekti. Vali, Belediye Başkanı ve İsmet Paşa da Gazi Mustafa Kemal Paşa'nın geleceğini sabah haber almışlardı. Şehirde ve özellikle ilk karşılama yeri olan Mudanya sahilinde heyecan ve hazırlıklar son raddedeydi.

İstanbul〉da bulunan Gazi Mustafa Kemal Paşa, yanında Türkiye Büyük Millet Meclisi (TBMM) Başkanı Kâzım Paşa (Özalp), Dışişleri Bakanı Tevfik Rüştü (Aras), Adalet Bakanı Mahmut Esat (Bozkurt), Sağlık Bakanı Dr. Refik (Saydam), Genel Sekreter Tevfik (Bıyıklığlu), İzmir Mebusu Saraçoğlu Şükrü, Gaziantep Mebusu Kılıç Ali, Bozok Mebusu Salih, Sinop Mebusu Recep Zühdü, Rize Mebusu Hüseyin Cavid beylerle Başyaver Rusuhi ve Muhafız Birliği Komutanı İsmail Hakkı (Tekçe) olduğu halde Ankara gemisiyle saat on dörtte Mudanya'ya gelmişlerdi. ${ }^{21}$

Gazi Mustafa Kemal Paşa'nın Bursa'yı teşrifleri İstanbul'dan Mudanya'ya giden Marmara vapuru yolcuları tarafından fark edilince Mudanya ahalisi de durumun farkına varmıştı. Marmara vapurundan iki saat sonra Mudanya'ya gelen vapur halkın dikkatini çekmişti. Ahali böylece sahile akın etmişti. Bu esnada Bursa Valisi Fatin Bey Mudanya'da bulunmuş ve kendilerini karşılamaya gitmişti. Gazi Paşa, mebuslar ve diğer refikası Ankara vapurundan tahsis olunan filikalarla sahile çıkmışlardı. Sahilde Vali Bey, Jandarma Kumandanı ve binlerce ahali tarafından karşılanmışlar, "Yaşa Gazi Paşa Hoş geldin, sefa geldin" sedaları ufka çıkmıştı. Gazi Paşa halkın hatırını sormuş ve derhal tahsis olunan otomobillerden birincisine Gazi Paşa, Meclis Reisi Kâzım Paşa, Başyaver Rusuhi Bey diğer otomobillere de mebuslar ve diğer zevat binerek halkın alkış tufanı arasında doğruca Bursa'ya teşrif etmişler ve İsmet Paşa'nın Köşklerine varmışlardı. İsmet Paşa, Gazi Mustafa Kemal Paşa'nın geleceğinden evvelce haberdar olamadıklarından teşriflerinden haberdar olmalarıyla hemen hazırlıklara başladıklarını söylemiş̧i. ${ }^{22}$

Ankara vapuruyla Mudanya'ya ve oradan da Bursa'ya Büyük Halaskârı görmek ve alkışlamak için gelen kadın erkek tüm Bursa halkı Çekirge ile Köşk'ün arasındaki caddeyi doldurmuşlardı. Mustafa Kemal Paşa kentte bulunan Başbakan İsmet Paşa ile üç saatlik bir görüşme yapmıştı. ${ }^{23}$

18 Hâkimiyet-i Milliye, 16 Temmuz 1927,1,2; “İsmet Paşa Hazretlerine Tâzimat”, Cumhuriyet, 16 Temmuz 1927,2 .

19 "Gazi Hazretlerinin Seyahatleri Tafsilatı, İsmet Paşa ile Üç Saatlik Mülakat”, İkdam, 17 Temmuz 1927,1,2; "Reis-i Cumhur hazretleri dün Bursa'ya teşrif buyurdular", Hâkimiyet-i Milliye, 16 Temmuz $1927,1,2$.

20 http://www.enbursa.com/haber/1922-den-1938-e-ataturk-un-bursa-gezileri-1341.html(Erişim Tarihi.22.07.2020).

21 Özel, Nutuk'a Bir Bakış "Tertip ve Çeviri Hataları",7; "Reis-i Cumhur hazretleri dün Bursa'ya teşrif buyurdular", Hâkimiyet-i Milliye, 16 Temmuz 1927, 1,2; "Gazi Hazretlerinin Seyahatleri Tafsilat1, İsmet Paşa ile Üç Saatlik Mülakat”, İkdam, 17 Temmuz 1927, 1,2.

22 “Gazi Hazretlerinin Seyahatleri Tafsilatı, İsmet Paşa ile Üç Saatlik Mülakat”, İkdam, 17 Temmuz 1927, 1,2 .

23 "Reis-i Cumhur hazretleri dün Bursa'ya teşrif buyurdular", Hâkimiyet-i Milliye, 16 Temmuz 1927, 1,2; "Gazi Hazretlerinin Seyahatleri Tafsilatı, İsmet Paşa ile Üç Saatlik Mülakat”, İkdam, 17 Temmuz 1927, 
Gazi Mustafa Kemal Paşa'nın İsmet Paşa ile üç saat kadar devam eden görüşmesinden sonra Köşk'ten çıkarak ahalinin alkış tufanı arasında Cumhuriyet Kasrı'na gitmişlerdi. Daha sonra İsmet Paşa'ya veda ederek otomobillerle Mudanya'ya dönmüşlerdi. Gazi Paşa ve beraberindekiler Seyr-i Sefâin dairesinden gönderilen Kartal römorkörüyle Ankara vapuruna geçmişlerdi.

Mudanya ahalisi sahilde toplanarak Gazi Paşa'nın bindiği vapur hareket edinceye kadar "Yaşa var ol, çok yaşa" sedalarıyla alkışlarına devam etmişlerdi. Ankara vapuru elektrikle mükemmel şekilde aydınlatılmış, Riyaset-i Cumhur Orkestrası terennüm eyleyerek saat yirmi bir de Mudanya'dan hareket etmişti. Deniz sakin ve mehtap denize vurmuştu. Gazi güverteden mehtabı izlemişti. Güzel deniz havası alarak geçen yolculuk saat yirmi dörtte son bulmuş ve İstanbul limanına ulaşmışlardı. Gazi Paşa öğle ve akşam yemeklerini Ankara vapurunda yemiş ve açılan Ankara Vapuru hatıra defterine seyahati ile ilgili düşüncelerini yazmıştı. ${ }^{24}$

Gece saat on ikide Ankara Vapuru Boğaza doğru çıkarken Tarabya'dan dönmekte olan Etibba Cemiyeti'nin vapuruna tesadüf etmişlerdi. Dolmabahçe açılarında burun buruna gelen vapurdan doktor ve aileleri tarafindan "Yaşa Gazi" sesleri yükselmişti. Ankara vapurunda bu sırada caz bant ve ince saz çalmaktaydı. Gazi Mustafa Kemal Paşa bundan sonra Ankara motoruna binerek doktorların etrafinda bir tur attıktan sonra Dolmabahçe'ye inmişti. ${ }^{25}$

Gemlik'ten gelen hanım ve erkeklerden oluşan heyetlerin İsmet Paşa ve eşlerini Gemlik'e davet etmeleri ve Paşa'nın da bu daveti olumlu cevaplamaları üzerine Gemlik ve civar köylerde hazırlıklar başlatılmıştı. İsmet Paşa'nın sağlığı elverişli olursa köy halkı da Paşa'yı misafir etmek istemekteydi. Bu yüzden köyler dahi zafer takları ile süslenmişti. Mevhibe Hanım için de Gemlikli hanımlar bir konak tahsis ederek burada hazırlıklara başlamışlardı. Bunun yanında kutlamalarda balo tarzı bir düzenleme söz konusu değildi. Mümkün olduğunca halkla beraber olunması hedeflenmekteydi. ${ }^{26}$

İsmet Paşa 18 Temmuz günü Vali Fatin Bey’le şehirde Emir Sultan'a kadar bir gezinti yapmışlar ve bilahare yeni yapılan Gündoğdu köyünü görmek üzere Filadar mevkiine kadar gitmişlerdi. Paşa daha sonra Kükürtlü bahçesinde biraz dinlenmişti. ${ }^{27}$

İsmet Paşa 19 Temmuz günü askeri liseyi gezmişti. Maliye Vekili Abdülhalik, Siirt Mebusu Mahmut ve Başvekâlet Müsteşarı Kemal beyler Bursa'ya gelerek üç saat kadar İsmet Paşa'nın yanlarında kalmışlardı. ${ }^{28}$

Dahiliye Vekili Cemil Bey 21 Temmuz günlü trenle Bursa'ya hareket etmişti. Cemil Bey’i istasyonda Müdafaa-i Milliye Ticaret ve Ziraat Vekilleri ile mebuslar, diğer devlet erkânı ve birçok

1,2; Cumhuriyet, 16 Temmuz 1927, 1,2; “Gazi Hazretleri Dün Bursa'ya Gittiler”, İkdam, 16 Temmuz 1927.

24 “Gazi Hazretlerinin Seyahatleri Tafsilatı, İsmet Paşa ile Üç Saatlik Mülakat”, İkdam, 17 Temmuz 1927, 1,2 .

25 Dolmabahçe açıklarında burun buruna gelen vapurdan doktor ve aileleri "Yaşa Gazi, Gazi Hazretleri", Hâkimiyet-i Milliye, 17 Temmuz 1927, 1.

26 Musa, "Başvekilimiz", Cumhuriyet, 18 Temmuz 1927, 2.

27 "İsmet Paşa", Cumhuriyet, 19 Temmuz 1927, 2; "Başvekilimizin tenezzühü", Hâkimiyet-i Milliye, 22 Temmuz 1927, 1.

28 Musa, "Dün İsmet Paşayı ziyaret edenler", Cumhuriyet, 20 Temmuz 1927, 2; "Başvekâlet Müsteşarı", Hâkimiyet-i Milliye, 25 Temmuz 1927, 2. 
kişi uğurlamıştı. Cemil Bey istasyonda bir muhabir tarafından sorulan sorulara şöyle cevap vermişti: “Evvelce de üç beş gün sonra Istanbul'a gideceğimi söylemiştim işte gidiyorum. Bursa'da Başvekil Paşa hazretleriyle görüşeceğim. Belki İsmet Paşa Hazretleriyle beraber İstanbul'a gideriz". ${ }^{29}$

Dahiliye Vekili Cemil Bey 22 Temmuz 1927 tarihinde sabah saatlerinde Karaköy'den otomobille İnegöl'e gelmiş ve burada bir saat kadar istirahat ettikten sonra refakatinde Bursa Valisi Fatin Bey olduğu halde Bursa'ya doğru yola çıkmışlardı. Vekil Bey'in şerefine Halk Fırkası'nda bir çay ziyafeti verilmişti. ${ }^{30}$ Dahiliye Vekili Cemil Bey Ankara'dan yolcu edilirken gazetecilere verdiği beyanatta İsmet Paşa'nın da kendisiyle İstanbul'a dönebileceğini bildirmişti. Ancak Bursa'da birkaç gün kalan Cemil Bey İstanbul'a yalnız gitmişti. ${ }^{31}$

İsmet Paşa 23 Temmuz günü at ile Acemler Çekirge civarında bir gezinti yapmıştı. ${ }^{32}$

İsmet Paşa'nın Bursa'da bulunduğu tarihlerde Lozan Konferansı'nın da yıldönümüydü. Lozan Barış Konferansı İsmet Paşa'nın adıyla anılmaktaydı. İstanbul Darülfünûnu'nda düzenlenen toplantının ardından seçilen bir kurul Mustafa Kemal Paşa’yı ziyarete gitmiş ve kurul ile aralarında geçen söyleşide Gazi Mustafa Kemal Paşa “Lozan görüşmelerini her türlü siyasi mücadelelere gögüs gererek sonuç almakta büyük bir uyanıklık gösteren İsmet Paşa hazretlerini saygıyla anmak görevimdir" cümleleriyle dördüncü yıldönümü yapılan Lozan Konferansı'nda sözü İsmet Paşa'ya getirerek başarılı duruşundan dolayı kendisini takdir etmişti. ${ }^{33}$ İsmet Paşa'nın adıyla birlikte anılan Lozan Konferansı'nın dördüncü yıldönümünde İsmet Paşa Bursa'daydı.

Bursa'da da 24 Temmuz günü Lozan Barışı'nı imzalamakla Türk milletinin şükran ve minnetlerini kazanan ve ülke için bayram kabul edilen bu günde İsmet Paşa'yı şehir namına tebrik etmek üzere otuz iki kişilik bir heyet Paşa'nın Çekirge' deki köşklerinde kabul edilmişti. Ali Hikmet Paşa'nın söyleşisi ile heyet gece de görüşmelere devam etmiş ve konuklar kabul salonunda Paşa'ya ayrı ayrı takdim edilmişlerdi. Bursalılar adına Paşa'ya bir buket verilerek heyet namına Vali Bey saygılarını sunmuştu. ${ }^{34}$

İsmet Paşa heyeti derin bir hisle karşılayarak yarım saatten fazla çok samimi muhabbette bulunmuş ve bu şerefli büyük günü anma vesilesiyle bu toplantıdan çok memnun kaldıklarını beyan etmişti. ${ }^{35}$

İsmet Paşa duygu ve düşüncelerini şu cümlelerle aktarmışt1: "Lozan gününde beni tatyib eden (mutlu eden) bu samimi alâka-i güzideden çok mütehassis oldum. Teşekkürler ederim ". ${ }^{36}$

İsmet Paşa devamında daha önce İstanbul'da bir gazetecinin kendisine sorduğu bugüne ait hisleriniz nedir sorusunu verdiği cevabı bu konuşma sırasında yinelemiş ve şunları söylemişti:

"Dahiliye Vekilimiz Bursa'ya Hareket Etti", Cumhuriyet, 22 Temmuz 1927, 1,2.

Ahmet Hamdi, "Dahiliye Vekilimiz Bursa'da", Cumhuriyet, 23 Temmuz 1927, 1.

"Dahiliye Vekilimiz dün Bursa'dan geldi", Cumhuriyet, 24 Temmuz 1927, s.1; "Dahiliye Vekilimiz Bursa'ya Gitti”, Hâkimiyet-i Milliye, 22 Temmuz 1927, 1.

"Başvekilimizin tenezzühü”, Hâkimiyet-i Milliye, 27 Temmuz 1927, 1.

Özel, Nutuk'a Bir Bakış "Tertip ve Çeviri Hataları",8-9.

Musa, "Lozan Kahramanı", Cumhuriyet, 25 Temmuz 1927, 1,2; "Başvekilimizi Tebrik", Hâkimiyet-i Milliye, 28 Temmuz 1927.

"Başvekilimizi Tebrik", Hâkimiyet-i Milliye, 28 Temmuz 1927.

Musa, “Lozan Kahramanı”, Cumhuriyet, 25 Temmuz 1927, 1,2. 
"Lozan muahedesinin tarihimizde farklı olan esasl hassası Türkiye'nin garp usulünde müstakil ve milli bir devlet olması hakkının beynelmilel sahada müşahede ve tasdik edilmiş olmasıdır. Müş̧ahid ve tasdik diyorum, çünkü böyle neticeleri fiilen istihsal etmek esasen ve ancak çetin bir muhadele ile mümkündür. Osmanl İmparatorluğu'nda ve diğer Şark memleketlerinde Avrupa usulünde bir milli devlet kabul olunmamasının birçok sebepleri vardır. Evvela milli bir devlet mefhumunu şuur ile anlayacak yüksek idrak lâzımdır.

Saniyen milli ihtiyacı tatmin edinceye kadar uğraşacak enerjiye malikiyet şarttır. Bu gibi şartların fiiliyatda tezahürat ve icraatı senelerce ve senelerce sebata lüzum gösterir. Ancak bu şeraiti tahakkuk ettirdikten sonradir ki bir milletin yüksek muamele görmeye müstahak olduğunu müşahede ederiz. Lozan'dan sonra geçirdiğimiz seneler itimatla der-hatır olunmağa lâyıktır. Lozan senetlerinde milletimizin seviyesi ve istihkakı fevkinde neticeler elde edilmiş olduğunu iddia eden bedhahlarımı bu geçen dört sene zarfinda meyus olmuşlardır. Dört seneden beri milletimizin gösterdiği idrak ve kudret ve bunların netayici olan mevcut inkişafat Lozan'da bizim tasavvurumuzun fevkinde bir netice elde edildiğini ispat etmişstir.

Bu hissi halimiz âti içinde nazarı dikkatimizi esasl noktalarda celp edebilir. Bedhahların düşündükleri zaaf ve aczin Türkiye'de görünemeyeceğini ve görünememesi lâzım olduğunu söylemiş oluyorum.

Filhakika zamanin gerek iktisaden ve gerek idare ve siyasetçe manen ve maddeten kuvvetli olmaya ihtiyacı olduğunu iyice bilmek lâzımdır. Lozan'daki ve Lozan'dan beri istihsal ettiğimiz neticeler elimizde tutulması ve mütemadiyen mesut inkışafata mazhar kllabilmesi ancak idarenin maddeten ve manen muktedir ve kuvve-i insanlar elinde bulunmast ile kabildir. Zaafin bu neticeleri süratle elinden çıkaracağl şüphe yoktur. Bunu nesl-i âtiye bir hatıra olmak üzere huzur-l güzide tekrarlyyorum.

Lütufkârane tekrar hararetle teşekkür ediyorum ". ${ }^{37}$

Çeşitli konuların görüşülüp sohbet edildiği bu toplantıda iktisadi bir konu münasebetiyle İsmet Paşa Bursa'nın ekonomik durumu ile ilgili de şunları söylemişti:

"Geçenlerde Belediye'de Bursa'nin servetinden bahsediyorduk. Bursa'da iktisaden durgunluk olduğunu söylediler. Ben böyle bir durgunluğa hiç bir sebep göremiyorum. Burası hem ziraat, hem zanaata çok müsaittir. Ziraat, nafia vasi mikyasta inkışaf edebilir. Burada ilk geldiğim gün içtiğim sütün Ankara'da içtiğim sütten çok farkl olduğunu derhal fark ettim. Bursa'nın otlarını, meralarını görüyorum. Mükemmel bir sanayi, ziraiye merkezi olabileceğine kanaat hâsıl ediyorum.

Kezalik burası çok meralı hayvanat ıslah merkezi de olabilir. Her taraftan at, koyun, almak için buraya kadar gelirler. Yakında Hara'ya gideceğiz. Karacabey Harası'nı bütün memleket için iyi bir merkez haline getirmek ihtiyact vardır. Suret-i mahsûsada bununla meşgul olacağım. At, boğa, koyun sürülerinden Türkiye’ye mahsus mükemmel bir tip yetiştirmek pek mümkündür. Yalnız haraya karşı etraftaki telakkiyi çetin görüyorum. Karacabey ovasına, toprağına etraftakiler hep düşmandır. Herkes gözünü bu Karacabey Harası'na dikmiştir. Biran evvel taksim edilip dağılmasını bekliyorlar. Bu münasebetle söylemek istiyorum ki bu hara yalnız Bursa'nın mahalli

37 Musa, "Lozan Kahramanı", Cumhuriyet, 25 Temmuz 1927, 1,2; "Muhterem Başvekilimizin Lozan Sulhunün İmzası Yıldönümünde Kıymetli İhtisasları", Hâkimiyet-i Milliye, 26 Temmuz 1927, 1. 
bir müessesesi değil; memleket için bir mektep, bir damızlık yeri olacaktır. Herhalde bu takibi değiştirmek lâzımdır.

Sonra dikkatinizi ve alâkanızı bilhassa tahrik ederim diye söyleyeceğim ki Bursa gerek ipek ve gerek yün dokumaları için bizim çok ümit beslediğimiz bir merkezimizdir. Bu dokumaların yüksek sanayii burada vasi surette inklşaf ettirmek lâzımdır". ${ }^{38}$

Vali Bey’in İsmet Paşa'ya hatır sormasına karşılık Paşa, Bursa'da kaplıcalardan fayda gördüğünü ve sağlığının iyiye gittiğini söylemişti. Birkaç gün önce de ata bindiğini ve ata binmenin kendisine hareket sağladığı için kendisini daha sağlıklı hissettiğini belirtmişti. ${ }^{39}$ İsmet Paşa daha önce de 11 Temmuz 1927 tarihli bir mektupla düzenli olarak kükürt banyosuna başladığını, sağlı̆̆ının iyiye gittiğini, Bursa kaplıcalarının tedavisine iyi geldiğini Gazi Mustafa Kemal Paşa’ya da bildirmişti. ${ }^{40}$

İsmet Paşa 25 Temmuz günü atla Beledi Yunus (Yunuseli) köyü civarına kadar bir gezinti yapmıştı. ${ }^{41}$ İsmet Paşa'nın ikamet ettiği Çekirge'deki Köşk’le Beled-i Yunus köyü arası yaklaşık 10 km'lik bir uzaklıktayd1.

İsmet Paşa 26 Temmuz günü Bursa'da yeni açılan mensucat şirketiyle Hacı Sabri Efendi’nin ipek mensucat ve Cemali Yusuf Bey'in ipek fabrikalarını gezmişti. Kendisine verilen izahatla beraber bu teşebbüslerin Bursa'daki girişimlerinden, fabrikaların gelişmesinden ve fabrikaların işleyişinden memnun kalmıştı. ${ }^{42}$

Dahiliye Vekili Cemil Bey İstanbul'dan Ankara'ya dönüşünde yeniden İsmet Paşa'yı ziyaret etmişti. Ayrıca Trakya seyahatinden dönen CHF Müfettişi İbrahim Tali Bey'de Bursa'da İsmet Paşa ile görüşmüştü. ${ }^{43}$

\section{3. İsmet Paşa'nın Bursa Yakınlarına Yaptığı Seyahatler}

İsmet Paşa Bursa'da bulunduğu süre içerisinde Balıkesir'e de gitmişti. Ayrıca Balıkesir yolu üzerinde Bursa'ya bağlı Karacabey’e de ziyarette bulunmuştu. İsmet Paşa 29 Temmuz günü Balıkesir'e gitmişti. İsmet Paşa Pazar günü Bursa'ya dönmüş ve Pazartesi günü Bursa'dan ayrılarak İstanbul'a hareket etmişti. ${ }^{44}$

İsmet Paşa refakatlerine Ali Hikmet Paşa ile yaverleri Atıf ve Fikret beyler, Vali Fatin Bey, Jandarma Kumandanı Tahsin Bey, Doktor Şemseddin ve Sabri beyleri alarak 29 Temmuz günü saat yedi kırk beşte kendisini uğurlamaya gelenlerle samimi bir surette veda ederek Karacabey’e gitmek üzere Bursa'dan ayrılmıştı. İsmet Paşa’yı Vali Fatin, Fırka Müfettişi Kemaleddin, Jandarma Müfettişi Halil Fikri, Jandarma Kumandanı Tahsin, Tabip müdavimleri Kaymakam Şemseddin

\footnotetext{
38 Musa,“Lozan Kahramanı”, Cumhuriyet, 25 Temmuz 1927, 1,2.

39 Musa ,"Lozan Kahramanı”, Cumhuriyet, 25 Temmuz 1927, 1,2.

40 Devlet Arşivleri Başkanlığı Cumhuriyet Arşivi (BCA), 30.10.00-1.2.10.1.

41 Musa, “Baş Vekilimizin Tenezzühü”, Cumhuriyet, 26 Temmuz 1927, 2.

42 Musa, "İsmet Paşa”, Cumhuriyet, 27 Temmuz 1927, 2.

43 “İsmet Paşa Ağustos bidayetinde gelecek”, Cumhuriyet, 27 Temmuz 1927, 1; “Dahiliye Vekilimiz Dün Bursa'ya gitti”, Cumhuriyet, 28 Temmuz 1927, 2.

44 “İsmet Paşamız Pazartesi günü geliyor”, Cumhuriyet, 29 Temmuz 1927, 2.
} 
ve Kaymakam Nüzhet beylerle, Kalem-i Mahsûsa'dan Ali Rıza, Kolordu yaveri Rasim beyler otomobillerle takip etmişlerdi. ${ }^{45}$

Bu ziyaret sırasında Karacabey Harası'nın gezilmesi, detaylı bilgi alınması hedeflenmekteydi. Karacabey Harası Bursa-Balıkesir-İzmir yolu üzerinde Karacabey ile Mustafakemalpaşa ilçeleri arasında bulunan büyük devlet harasıydı. ${ }^{46}$ Karacabey Harası 1924 yılında Ziraat Vekâleti'ne bağlanmış ve 29 Mayıs 1926 tarihinde TBMM'de kabul edilen 867 Sayılı Yasa ile "Karacabey Harası" adını almıştı. ${ }^{47}$ Seyahatin gerçekleştiği yıl olan 1927 yılında Karacabey Harası Müdürü Emin Aybar'dı. Yine aynı tarihli Bursa Salnamesi'nde Karacabey Harası şöyle tanıtılmaktaydı:

"Vaktiyle Mihaliç Çiftlikât-1 Hümâyûn namıyla yadolunub ilân-1 meşrutiyetten sonra Mihaliç kazasının ismi merkez kazada medfûn Karacabey'e izafeten Karacabey Kazası'na ve çiftlik namı dahi Karacabey çiftlikâtı olarak tevsim edilmişti. Doğrudan doğruya hazine-i hakaniyeye merbut olan mezkûr çiftliğin esas tesisi hakkında kuyûd-u tarihiye mevcut değilse de çiftlikte otuz seneden beri ifâ-yı hüsn-ü hizmet eden elyevm haranın müdür muavini olan Emin Bey'in malûmatına göre elyevm çiftlikâtın ufak bir parçasını Sultan Orhan'a verilen kıza çeyiz olarak verildiğini ve bilahare civardaki araziler iştira suretiyle ilave edilerek tevsi' edilmiş olduğu rivayet edilmektedir. Çiftlik Karacabey kaza merkezine $58 \mathrm{~km}$ mesafede ve kazanın kısmı cenubunda münbit ve mahsuldar araziye havidir. Çiftlik arazisi 98.767 dönümlük arazidir.

Haranın maksad-ı tesisi: Karacabey'de tesis edilen haranın maksad-ı tesisi memleketimizin iktisadiyatıyla şiddetle alâkadar olan matlûbe muvafik ve iklim ile alışmış memlekete lüzumu olan damızlıkların meydana getirilmesine çalı̧̧maktadır". ${ }_{48}$

İsmet Paşa özellikle atlara meraklıydı. Bu sebeple devletin bu büyük harasında cins atlar yetiştirilmesini arzu etmekteydi. Bununla ilgili olarak çalışmalar başlatan Başbakan İsmet Paşa aynı tarihlerde Yarış ve Islah Encümeni kurulmasını sağlamış ve Ankara'daki Haziran yarışlarının ikinci hafta yarış gününe "Gazi Koşusu" ${ }^{49}$ nun eklenmesi kararlaştırılmışt1. ${ }^{50}$

İsmet Paşa ve refakatindekiler uzun ve kısmen harap bir şoseyi takiben Apolyont (Ulubat Gölü)'a ulaşmışlardı. İskeleye gelenlerle samimi bir sohbette bulunmuşlardı. Geniş tarlaları

45 "Başvekilimiz Balıkesir'de tezahüratla karşılandılar", Cumhuriyet, 30 Temmuz 1927, 2; "Muhterem Başvekilimiz Paşa Hazretleri dün otomobille Bursa'dan Balıkesiri’ne gittiler”, Hâkimiyet-i Milliye, 31 Temmuz 1927, 1; "İsmet Paşa Hazretleri Pazartesi günü İstanbul'a geliyor", Cumhuriyet, 30 Temmuz $1927,1$.

46 Murat Çubukçu, Halit Ersöz, "Gazinin Tayları" Çiflikat-ı Hümayun'dan Tigem'e Karacabey Harası (Bursa: Nilüfer Belediyesi, 2015), 21.

47 Çubukçu-Ersöz, 27.

48 “Karacabey Harası”, 1927 Bursa Salnamesi (Bursa: Bursa Vilayet Matbaası,1927), 197- 202.

49 Gazi Koşusu ilk defa 10 Haziran 1927 yılında 2000 metre mesafede tertiplenmiştir ve para ikramiyesi de 2000 TL.dir. İlk Gazi Koşusu'nu Hacı Bekirzade Ali Muhittin Bey'in sahibi olduğu Neriman adlı Safkan İngiliz kısrağ Jokeyi İhsan Atçı ile kazanmıştı.

501927 y1lı içerisinde başlayan ve günümüzde de devam eden "Gazi Koşusu" na da ilgi duyan İsmet Paşa’nın "Olgo" isimli atı 1930'da birinci olmuştu. Ayrıca İsmet Paşa'nın ata olan ilgisi uluslararası alanda da bilinmekteydi. İsmet Paşa 1932 yılında Sovyetler Birliği gezisinde Moskova'da kendi adıyla onuruna düzenlenen at yarışını izlemiş ve 3 Mayıs'ta 1.500 metrelik mesafeyi 1,56.6 dakikada birinci olarak bitiren Rüzgâr isimli yarış atı kendisine hediye edilmişti. Bkz. Sabahattin Özel, Mustafa Kemal Atatürk Yeni Gerçekler Yeni Düşünceler, İkinci Basım (İstanbul: Türkiye İş Bankası Kültür Yayınları, 2018), 220. 
kaplayan Karacabey Harası'nın başlık demirleri seyrine doyulmaz bir manzara teşkil ediyordu. Yolda intizamla dizilmiş fenni arı kovanları nazarı dikkati çekiyordu. Uzaktan kışla manzarası veren bu muazzam Hara binalarında hayvanat için çok güzel bölmeler yapılmıştı. Bu bölmeler bütün döşemelerle fenni ve temiz tutulan ahırlarda muhtelif ırklara mensup cins hayvanlar doluydu. Fakat İsmet Paşa bu çeşitli hayvanlar arasında Karacabey’e has, muayyen ve mükemmel bir 1rk ortaya çıkarılması için ısrarcı ve kararlıydı.

Paşa bütün inceliklerine ve teferruatına kadar Hara'yı tetkik ve teftiş buyurdu. Macar uzmanın ${ }^{51}$ ifadesine göre burada mükemmel bir Türk cinsi at yetiştirmek faydalı olacaktı. Görünen damızlık aygırların içinde yarış ve ıslah encümeni namına İsmet Paşa tarafından satın alınan Hara'ya hediye edilen halis eldem İngiliz aygır1 ${ }^{52}$ bilhassa nazarı dikkati celp ediyordu. Binanın ortasında idman pisti mevcut, haricinde padoklar vardı. Paşa bu pistlerin çoğaltılması için de emirler verdi.

Sonrasında çeşitli bölümler, kendi branşları dahilinde Paşa’ya bilgi vermişlerdi. İzahatı müteakip Hara'nın büyük salonunda öğle yemeği yenilmiş, yemekte de Hara hakkında fikir alışverişinde bulunmuşlardı. Bilhassa çok kıymetli Arap hayvanlarından Memduh ve Ferhan adlı cins hayvanların nesillerini muhafaza için emir vermişler ve sonrasında Balıkesir'e doğru hareket etmişlerdi.

Taşköprü mevkiinde mebuslardan Osman, Niyazi ve Ali Sururi beylerle Balıkesir Valisi ve Fırka mutemedi beyler İsmet Paşa ve heyetini karşılamaya gelmişlerdi. Susurluk'tan geçen heyet, asker, halk mızıkanın tezahüratı arasında candan ve samimi görüntülere şahit olmuştu. Paşa belediyede biraz istirahat buyurduktan sonra heyetleri kabul etmiş ve kendileriyle ayrı ayrı ilgilenip sohbet etmişti.

Bor asit madeni ocaklarının yanından geçerken Paşa yine otomobilden inerek, bölgedeki mühendisleri selamlamıştı. Halk yol üzerinde mükemmel bir zafer takı yapmış, köy yolları üzerinde de bir kaç zafer takıyla karşılaşmışlardı. ${ }^{53}$

İsmet Paşa altıyı yirmi beş geçe halkın coşkun tezahüratı arasında Balıkesir'e ulaşmıştı. Edremit, Sındırg1, Balye, Gönen, Bandırma, Susurluk, Burhaniye, Ayvalık ve Balıkesir muhitlerine ayrı ayrı iltifat buyurarak alkış tufanı ve kesif bir insan çerçevesi içinde belediyeye doğru ilerlediler. Halkın "Yaşasın Sevgili Başvekilimiz, Yaşasın Paşamız!" sedaları sokakları çınlatıyordu. Paşa her tarafa ayrı ayrı "Merhaba asker, Merhaba Efendiler, Nasılsını hanımlar!" diye iltifatta bulunuyordu. Balıkesir halkı bir haftadır Başvekili bekliyor ve hazırlıklar yapıyordu. Halk birbirleri arasında ezilme tehlikesi yaşıyordu. Belediyede istirahat eden Paşa sonra askeriyeye geçmişti. Saat dokuz otuzda mahfel-i askeriyede belediye tarafından bir ziyafet verilmişti. Ziyafete İsmet Paşa, yaverleri ve erkân-1 hükümetle, heyetler dahil yüz elliden fazla kişi katılmıştı. Dans ve askeri caz bandosunun müzik ziyafetleri vardı. Baloda Paşa'nın yaverlerinden Atıf ve Fikret beylerle Kolordu Yaveri Rasim Bey de vard1. ${ }^{54}$

51 Bu kişi atçılık uzmanı Dr. Ferenc Ckiky olmalı. Çünkü kendisine 1928 tarihinde Karacabey atçılık şubesinin düzenlenmesi için kadro tahsis edilmişti. Bkz. BCA, 30.18.1; 27.81.20.

52 Atatürk Kitaplı̆̆ı'nda bulunan kartpostallar arasında rastladığımız tarihsiz bir kartpostalda yazan "Karacabey Kazası'nda İsmet Paşa'nın 16.000 liraya alınan Akrobat namında aygır" notuna dayanarak sözü geçen hediyenin bu olabileceği kanısını taşımaktayız. Kartpostal için Bkz. Ek.4.

53 Musa, "Başvekilimiz Balıkesir'de tezahüratla karşıllandılar", Cumhuriyet, 30 Temmuz 1927, 2.

54 Musa, "Başvekilimiz Balıkesir'de tezahüratla karşılandılar", Cumhuriyet, 30 Temmuz 1927, 2; 
İsmet Paşa'ya Türk Ocağı tarafindan özel bir öğle ziyafeti verilmişti. Bu ziyafette İstanbul mebusu Edip Servet, Karesi mebusları Ali Sururi ve Osman Niyazi beylerle, Ali Hikmet Paşa, Bursa ve Balıkesir Valileri, Halk Fırkası Müfettişi, heyetler rüesası ve yaverler hazır bulunmuşlardı. İsmet Paşa Balıkesir'e ait memleket işlerinin en ince noktalarıyla ve bütün teferruatıyla yakinen alâkadar olmuştu. ${ }^{55}$

\section{4. İsmet Paşa Bursa'dan Ayrilıyor}

Riyaset-i Cumhur Katib-i Umûmisi Tevfik Bey 31 Temmuz günü "Ertuğrul” yatıyla Mudanya'ya gelmişti. Başvekil İsmet Paşa seyahat programına göre 1 Ağustos saat üçte İstanbul'a ulaşmış olacaktı. Sefâin Müdür-ü Umûmisi Sadullah Bey Mudanya'da İsmet Paşa'yı alacak heyetin içindeydi. Ertuğrul Yatı'nı Dolmabahçe Sarayı önünde demirleyecek ve İsmet Paşa Dolmabahçe Sarayı'nda Gazi Mustafa Kemal Paşa ile görüşecekti. ${ }^{56}$

Başvekil İsmet Paşa şerefine 31 Temmuz gecesi Bursa'da belediye dairesinde yüz kişilik bir veda ziyafeti verilmişti. ${ }^{57}$ İsmet Paşa ve ailesi misafiri bulundukları Bursa'dan İstanbul'a gitmek üzere 1 Ağustos sabahı saat on otuzda otomobiller ile hareket etmişlerdi. Refakatlerinde eşi, çocukları ve yaverleri bulunmakta idi. Bursalılar misafirlerini hararetli bir surette uğurlamış ve coşkuyla alkışlamışlardı. İsmet Paşa'yı Mudanya'ya kadar geçirmek üzere Ali Hikmet ve Ali Said Paşalar ile Bursa Valisi Fatin Bey başta olmak üzere Bursa Halk Fırkası Reisi Kemal Bey ve firka erkânı, Belediye reisi ve azaları, Bursa'nın bilinen şahsiyetleri otomobillerle kendilerini takip ederek Mudanya'ya ulaşmışlardı.

Mudanya'da hazırlıklar önceden başlamış ve girişe iki tak yerleştirilmişti. Bu taklardan birinde "Hoş geldiniz sevgili hemş̧ehrimiz" diğerinde de "Mudanya hemşehrileriniz sizi hürmetle selamlar" ibaresi yazılıydı. Kaza kaymakamı başta olmak üzere erkân-ı hükümet ve memurin ve bir kıta askeriye saat ondan itibaren İsmet Paşa'yı uğurlamaya hazırlanıyordu. Bütün Mudanya halkı iskele caddesine toplanmışlar, Paşa'ya sesleniyorlardı. Saat on otuzda Bursa'dan hareket eden İsmet Paşa ve maiyeti, on bir otuzda Mudanya'ya vasıl olmuşlard. Mahalli erkânı-1 memurin, İsmet Paşa'yı geçirmişlerdi. İsmet Paşa caddeden iskeleye geçerken halkı şapkasıyla selamlamış, askere hatır sormuş ve Ertuğrul yatına binmiş̧ti. Halk iskelede hemşehrilerini uğurluyordu.

İsmet Paşa altı sene önce yapılan Mudanya Mütarekesi’ni anımsayarak Kaymakam'a binanın hangisi olduğunu sormuştu. İsmet Paşa Mudanya'ya gelince aklına gelen ilk olay Mudanya Mütarekesi oluyordu. Uzun süren müzakereler ve en şiddetli görüşmelerin yapıldığı o binayı unutması mümkün değildi. Şimdi bu bina yeşil panjurlarıyla sahile karşı sükûn içinde idi.

İsmet Paşa Bursa'dan Mudanya'ya kadar yol boyunca halk ve özellikle köylüler tarafından alkışlanmıştı. Mudanya halkı da büyük coşkuyla Paşa'yı karşılamış ve kendisinden ayrılmak

Cumhuriyet, 3 Ağustos 1927,1,2.

55 Musa, “İsmet Paşa Balıkesir Türk Ocağında Başvekilimiz bugün Bursa’ya yarın da şehrimize geliyor”, Cumhuriyet, 31 Temmuz 1927, 1.

56 "Muhterem Başvekilimiz Paşa Hazretleri dün otomobille Bursa'dan Balıkesiri'ne gittiler", Hâkimiyet-i Milliye, 31 Temmuz 1927, 1; "İsmet Paşa bugün şehrimizde", İkdam, 1 Ağustos 1927, 1; "Başvekilimiz", Son Saat, 2 Ağustos 1927, 1; “İsmet Paşa bugün İstanbul'a Geliyor”, Cumhuriyet, 1 Ağustos 1927, 1. 
istemiyordu.

İsmet Paşa Yata binince güvertesinden halkın tezahüratını izliyor ve onlara sevgiyle bakıyordu. Topluluğun önünde çocuklar toplanmıştı. Paşa çocuklara mektebe devam edip etmediklerini soruyor ve gittiklerine dair cevap alınca memnuniyeti artıyordu.

Ertuğrul Yatı on ikiyi otuz beş geçe Mudanya iskelesinden hareket etmişti. Mudanya'da bulunmakta olan Seyr-i Sefâin idaresinin Marmara vapuru tarafından düdükle selamlanmıştı.

Ertuğrul Yatı'yla Heybeli’ye başlayan yolculuk güzel geçmişti, hava oldukça iyiydi. Sadece Bozburun'da hafif bir dalgalanma olmuştu. Sadullah Bey yolculukta İsmet Paşa'ya refakat etmekteydi. Ertuğrul Yatı saat üçü çeyrek geçe Heybeli önünde demirlemiş, İsmet Paşa ve refakati üç otuzda adaya inmişlerdi. ${ }^{58}$

\section{5. İsmet Paşa'nın İstanbul'a Varışı}

İsmet Paşa Heybeliada' da şehirde bulunan erkân-1 hükümet yetkilileri, mebuslar, erkân-1 askeriye, CHF Erkânı, Vali Süleyman Sami, Şehremaneti Muhiddin beyler ve diğer yetkililer tarafindan karşılanmıştı.

Vali Bey saat on ikide Heybeliada'ya gitmişti. İsmet Paşa, kendisi ve ailesi için hazırlanan erkek kardeşi Hasan Rıza'ya ait olan Köşke ulaşmışlardı. ${ }^{59}$ Şükrü Naili Paşa, Vali Süleyman Sami, Konya Mebusu Refik, Polis Müdürü Şerif, Emniyet Umûm Müdür Muavini Hami, Adalar Mutemedi Doktor Esat beylerle, Cemiyet-i Umûmiye-i Belediye azasından hemen hepsi Heybeliada'ya gelmişler ve İsmet Paşa'yı karşılamışlardı. Ada halkı toplanmış, mektep talebeleri de muntazam bir şekilde karşılama töreninde hazır bulunmuşlardı. Mektepli kızlardan biri Paşa'ya bir buket takdim etmiş ve Paşa da hediyeyi kabul etmişti. Başvekil İsmet Paşa halkın sürekli ve şiddetli alkışları arasında iskeleden geçmişler ve Mekteb-i Bahriye önüne varmışlardı.

Paşa daha sonra Mekteb-i Bahriye bahçesine giderek bir müddet durduktan sonra biraderleri Rıza Bey’in köşküne azimet etmişlerdir. İsmet Paşa Köşke kadar yaya olarak gitmek arzusunu izhar etmiş ise de mesafe uzun olduğundan araba ile götürülmüşlerdi. Paşa mütemadiyen yolda halk tarafından alkışlanmıştı.

İsmet Paşa Heybeliada'da Köşkünde dinlenirken kendisini ziyarete gelenler de olmuştu. Dinlendikten sonra akşam saatlerinde Ertuğrul Yatı'yla Dolmabahçe Sarayı'na Gazi Mustafa Kemal Paşa'ya gitmek üzere yola çıkmıştı. Dolmabahçe önlerine ulaşmasını müteakip Cumhurbaşkanı Başyaveri Rusuhi Bey, Ankara motoruyla Ertuğrul Yatı'na giderek İsmet Paşa’ya refakatlerinde bulunan Gaziantep Mebusu Kılıç Ali, Bozok Mebusu Salih, Sinop Mebusu Recep Zühtü beyleri alarak saat dokuz kırk beşte Dolmabahçe Sarayı'nın rıhtımına çıkmışlardı. Orada Sıhhiye Vekili Refik, CHF Katib-i Umumisi Saffet, Doktor Neşet Ömer beylerle bazı mebuslar ve muhafız kıtaatı kumandanı Binbaşı İsmail Hakkı Bey tarafından karşılanmıştı.

İsmet Paşa doğruca saraya giderek üst kat salona Gazi Mustafa Kemal Paşa huzuruna çıkmıştı. İsmet Paşa büyük salondan geçerken gazetecileri görmüş ve bunlar kim diye sormuştu. Kılıç Ali

\footnotetext{
58 “İsmet Paşamız Heyecanlı Tezahürat Arasında Dün Heybeliada’ya Çıktılar”, Cumhuriyet, 2 Ağustos $1927,2$.

59 “Başvekilimiz", Son Saat, 2 Ağustos 1927, 1.
} 
Bey gazeteciler deyince, İsmet Paşa "Bunlar her zaman beni böyle beklerler!" demişti.

İsmet Paşa akşam yemeğini Dolmabahçe Sarayı'nda Gazi'nin huzurunda yemiş ve gece Heybeliada'ya dönmüştü. ${ }^{60}$

Yaptıkları görüşme sırasında da İsmet Paşa Bursa seyahatinden çok memnun kaldığını, ağrılarının hafiflediğini sadece ayağında hafif bir ağrı kaldığını söylemişti. Bursa'da şifa bulduğunu Halk Fırkası Müfettişi İbrahim Salih Bey’e de söylemiş̧i. ${ }^{61}$

\section{Sonuç}

1927 yılının Temmuz ayı Bursa şehri için oldukça yoğun geçmişti. Bursa'da görev yapan devlet yetkilileri 8-31 Temmuz arasındaki programlarını Başbakan İsmet Paşa'nın programına uygun olarak planlamışlardı.

İsmet Paşa'nın seyahati Bursa şehri için çok faydalı bir ziyaret olmuştu. Çünkü Türkiye Cumhuriyeti'nin yönetiminde en yetkili kişilerinden biri olan Başbakan'ın Bursa'daki gelişmeleri yakından takip etmesi, ilerlemelerle yakından ilgilenmesi Bursa halkına ve Bursalı girişimcilere de bir teşvik olmuştu.

Bursa Türkiye için gelecek vaat eden bir şehir olarak ekonomisiyle, ticaretiyle, tarımıyla, sanayisiyle, sağlık turizmi imkânlarıyla, doğal kaynaklarıyla ülkeye kaynak sağlayabilecek bir potansiyele sahipti. Bu zenginliğin devlet tarafindan desteklenmesinin gerekliliği Mustafa Kemal Paşa'nın da üzerinde durduğu bir konuydu. Mustafa Kemal Paşa da Bursa'ya yaptığı ziyaretlerde bu zenginliğe dikkat çekmekteydi.

İsmet Paşa'nın sağlık problemleriyle yakından ilgili olan bu ziyaret aynı zamanda ülke kalkınması açısından da değer taşımaktaydı. Örneğin Bursa'nın şehir planlaması anlamında gelişmesi yönünde bazı yerleşim yerlerindeki yeniden yapılanmayı İsmet Paşa'nın bu seyahati sırasında yakından görmesi ve incelemesi mümkün olabilmişti. Filadar bölgesine at üzerinde yaptığı gezide İsmet Paşa hem sağlık açısından fiziksel aktivitesini yapmış, hem de şehrin imarında yapılan gelişmeleri incelemiştir. Yine Karacabey Harası'na yaptığı ziyarette uzun vadede düşündüğü planlarının temellerini bu gezi sırasında inşa etme firsatını yakalamış, durumu yakından, yerinde inceleyerek gelecekteki hayvancılık idealini bu pilot bölge üzerinde kurmuştur.

Ayrıca dokumacılık ve ipek sahasında da önem arz eden Bursa şehrinin bu alandaki fabrikalarını, işletme yerlerini ziyaretler de programında ilk sıralarda yer almıştı.

Bursa hem halkıyla, hem girişimcisiyle, hem burada görev yapan devlet yetkilileriyle bu ziyaretten memnun kalmış ve fayda sağlamıştı. Mustafa Kemal Paşa'nın 15 Temmuz günü Bursa'ya gelişi ise bu memnuniyeti arttıran bir diğer ziyaret olmuştu. İsmet Paşa'nın Bursa'da bulunduğu tarihlerde Türkiye'nin bir bayram günü olarak kabul edilen, kurtuluş ve siyasi zaferinin belgesi olan Lozan Anlaşması'nın dördüncü yıldönümü de Bursa'da, İsmet Paşa ile birlikte kutlanmıştı. Bursa şehrini onurlandıran ve gururlandıran bu ziyaret hafizalarda uzun süre yer etmiş, tarihi belgelerin arasında unutulmaz olmuştur.

60 “İsmet Paşamız, heyecanlı tezahüratlar arasında Heybeli’ye çıktılar”, Cumhuriyet, 2 Ağustos 1927, 1,2.

61 “Başvekilimiz”, Hâkimiyet-i Milliye, 29 Temmuz 1927, s.1; "Başvekilin Muvasalatı”, İkdam, 2 Ağustos $1927,1$. 


\section{Kaynaklar}

\section{Arşiv Belgeleri}

Devlet Arşivleri Başkanlığı Cumhuriyet Arşivi (BCA), 30.18.1; 27.81.20.

BCA, 30.10.00-1.2.10.1.

\section{Gazeteler}

Cumhuriyet

Hâkimiyet-i Milliye

İkdam

Son Saat

\section{Kitap ve Makaleler}

1927 Bursa Salnamesi, Bursa Vilayet Matbaas1, Bursa 1927.

Ahmet Hamdi, “Dahiliye Vekilimiz Bursa'da”, Cumhuriyet, 23 Temmuz 1927:1.

Ahmet Nuri, "İsmet Paşa Hazretleri", Cumhuriyet, 9 Temmuz 1927:1.

Çubukçu, Murat- Ersöz, Halit, “Gazinin Tayları” Çiflikat-ı Hümayun'dan Tigem'e Karacabey Harast, Bursa: Nilüfer Belediyesi, 2015.

Malkoç, Eminalp, Cumhuriyet’ten Büyük Söylev'e Ankara-İstanbul İkilemi (1923-1927), İstanbul: Derin Yayınları, 2014.

Musa, "Başvekilimiz”, Cumhuriyet, 18 Temmuz 1927:2.

Musa, “Dün İsmet Paşayı ziyaret edenler”, Cumhuriyet, 20 Temmuz 1927:2.

Musa ,'Lozan Kahramanı”, Cumhuriyet, 25 Temmuz 1927:1,2.

Musa, “Baş Vekilimizin Tenezzühü”, Cumhuriyet, 26 Temmuz 1927:2.

Musa, “İsmet Paşa”, Cumhuriyet, 27 Temmuz 1927:2.

Musa, "Başvekilimiz Balıkesir'de tezahüratla karşılandılar", Cumhuriyet, 30 Temmuz 1927:2.

Musa, "İsmet Paşa Balıkesir Türk Ocağında Başvekilimiz bugün Bursa'ya yarın da şehrimize geliyor”, Cumhuriyet, 31 Temmuz 1927:1.

Özel, Sabahattin, Nutuk'a Bir Bakış “Tertip ve Çeviri Hataları”, İstanbul: Derin Yayınları, 2015.

Özel, Sabahattin, Mustafa Kemal Atatürk Yeni Gerçekler Yeni Düşünceler, İkinci Basım, İstanbul: Türkiye İş Bankası Kültür Yayınları, 2018.

TBMM Albümü (1920-2010), 1. Cilt, 1920-1950, İkinci Basım, Ankara: Gökçe Matbaas1, 2010.

\section{4.Çevrimiçi Kaynak}

http://www.enbursa.com/haber/1922-den-1938-e-ataturk-un-bursa-gezileri-1341.html

(Erişim Tarihi.22.07.2020). 


\section{Ekler}

\section{Ek.1}

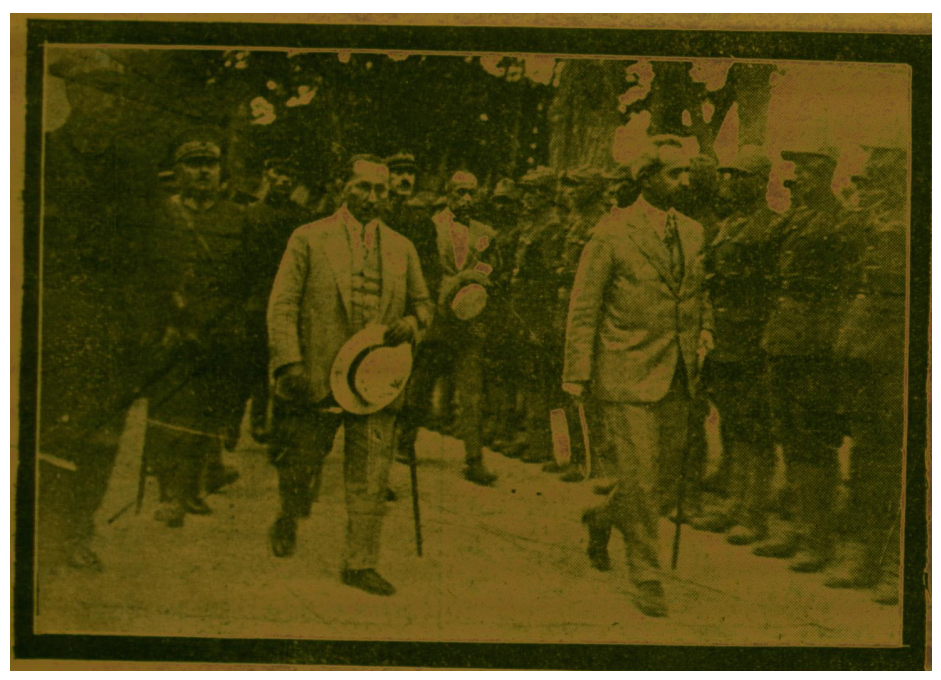

İsmet Paşa'nın Bursa'da karşılanışı. “Başvekilimiz İsmet Paşa Hazretleri Bursa'da...”, Cumhuriyet, 10 Temmuz 1927, s.1.

\section{Ek.2}

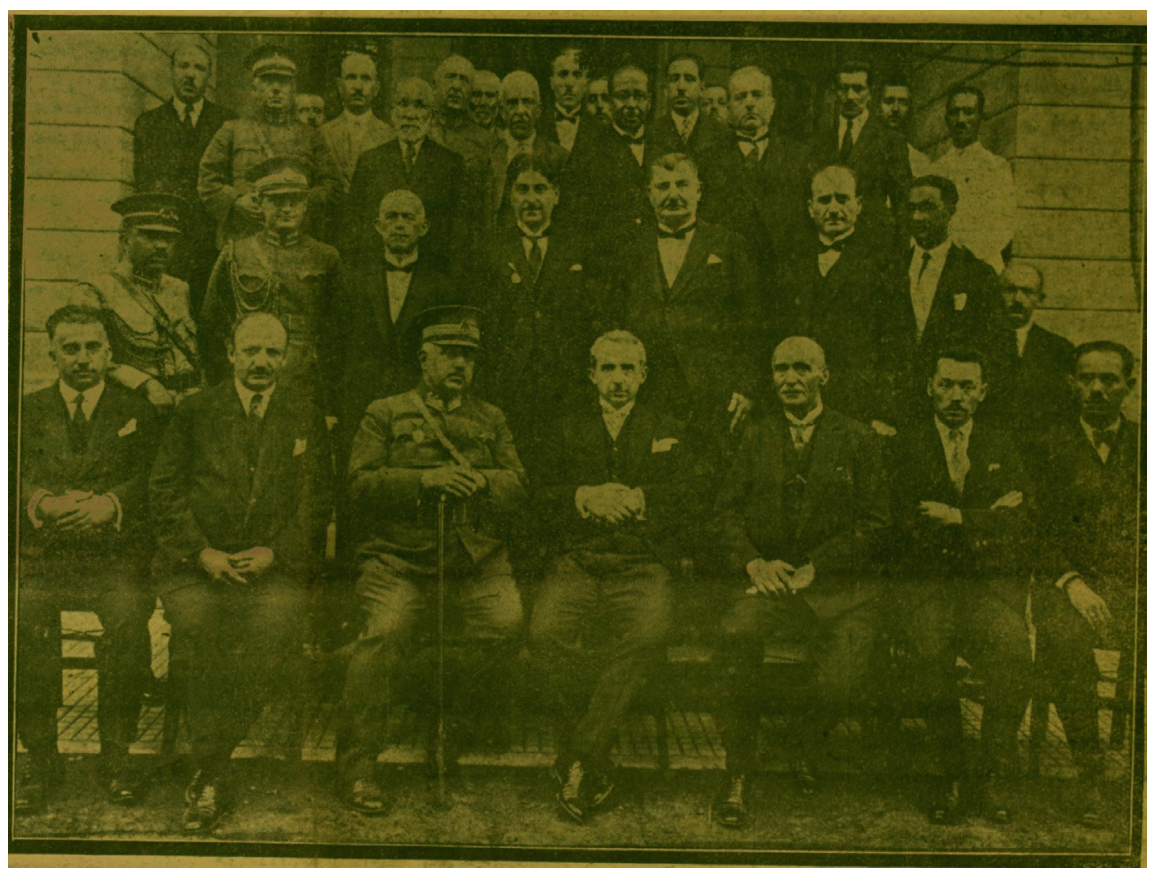

Başvekil İsmet Paşa Hazretlerinin, evvelki gün Bursa Halk Fırkası Merkezi ziyaretleri esnasinda alınan grup resim, Cumhuriyet, 16 Temmuz 1927, s.1. 


\section{Ek.3}

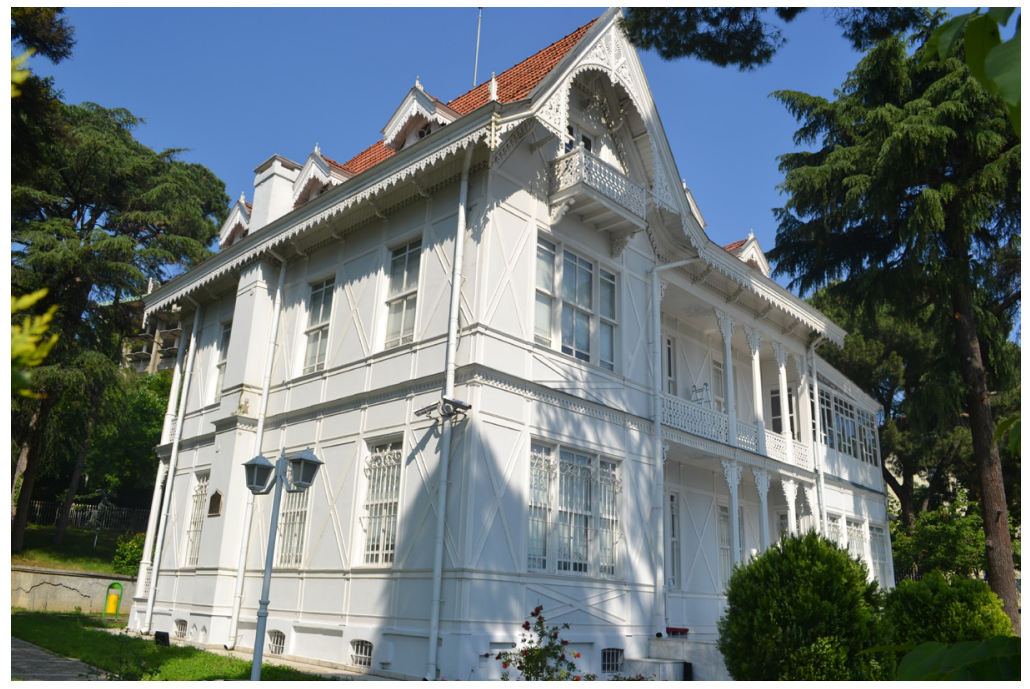

İsmet Paşa’nın kaldığı Köşk: Atatürk Köşkü, günümüzde Atatürk Evi Müzesi olarak hizmet vermektedir.

\section{Ek.4}
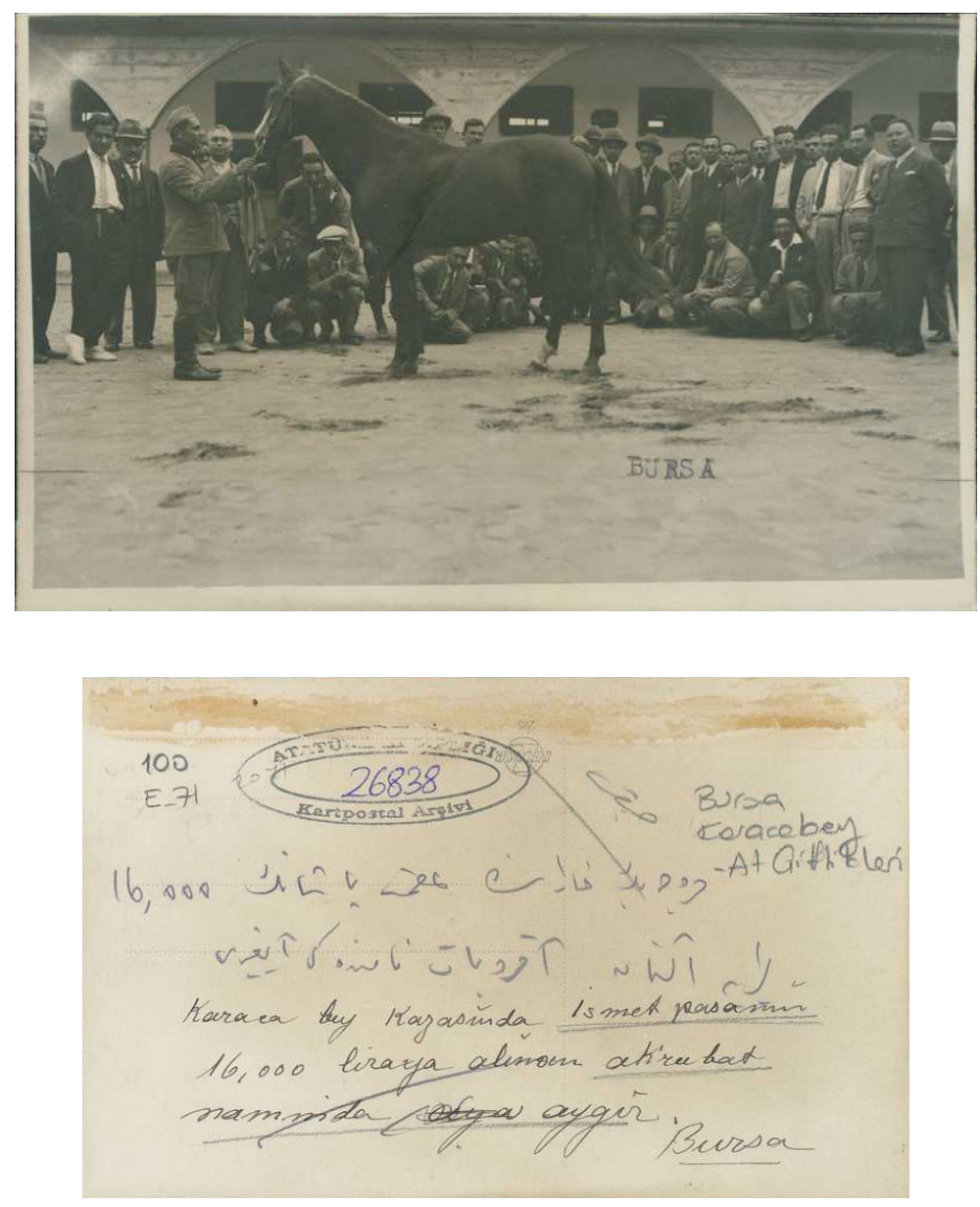

Karacabey Kazası'na hediye edilen Akrobat isimli at. 